\title{
Article \\ Dysregulations of Expression of Genes of the Ubiquitin/SUMO Pathways in an In Vitro Model of Amyotrophic Lateral Sclerosis Combining Oxidative Stress and SOD1 Gene Mutation
}

\author{
Audrey Dangoumau ${ }^{1,+}$, Sylviane Marouillat ${ }^{1,+}$, Roxane Coelho ${ }^{1} \mathbb{D}$, François Wurmser ${ }^{1}$, Céline Brulard $^{2}$, \\ Shanez Haouari ${ }^{1}$, Frédéric Laumonnier ${ }^{1}$, Philippe Corcia ${ }^{1,3}$, Christian R. Andres ${ }^{1,4}$, Hélène Blasco ${ }^{1,4}$ \\ and Patrick Vourc' ${ }^{\prime}$ 1,2,4,*
}

Citation: Dangoumau, A.;

Marouillat, S.; Coelho, R.; Wurmser

F.; Brulard, C.; Haouari, S.;

Laumonnier, F.; Corcia, P.; Andres,

C.R.; Blasco, H.; et al. Dysregulations

of Expression of Genes of the

Ubiquitin/SUMO Pathways in an In Vitro Model of Amyotrophic Lateral Sclerosis Combining Oxidative Stress and SOD1 Gene Mutation. Int. J. Mol. Sci. 2021, 22, 1796. https://doi.org /10.3390/ijms22041796

Academic Editor: Angelo Poletti

Received: 4 January 2021

Accepted: 2 February 2021

Published: 11 February 2021

Publisher's Note: MDPI stays neutra with regard to jurisdictional claims in published maps and institutional affiliations.

Copyright: (c) 2021 by the authors. Licensee MDPI, Basel, Switzerland. This article is an open access article distributed under the terms and conditions of the Creative Commons Attribution (CC BY) license (https:// creativecommons.org/licenses/by/ $4.0 /)$.
1 UMR iBrain, Université de Tours, Inserm, 37000 Tours, France; audrey.dangoumau@gmail.com (A.D.); sylviane.marouillat@univ-tours.fr (S.M.); coelho.roxane@gmail.com (R.C.); francois.wurmser@gmail.com (F.W.); shanez.haouari@etu.univ-tours.fr (S.H.); frederic.laumonnier@univ-tours.fr (F.L.); philippe.corcia@univ-tours.fr (P.C.); andres@med.univ-tours.fr (C.R.A.); helene.blasco@univ-tours.fr (H.B.) UTTIL, CHRU de Tours, 37000 Tours, France; C.BRULARD@chu-tours.fr Service de Neurologie, Centre de Référence sur la SLA, CHRU de Tours, 37000 Tours, France

4 Service de Biochimie et de Biologie Moléculaire, CHRU de Tours, 37000 Tours, France

* Correspondence: vourch@med.univ-tours.fr; Tel.: +33-(0)-234-378-910

$\dagger$ These authors contributed equally to this work.

Abstract: Protein aggregates in affected motor neurons are a hallmark of amyotrophic lateral sclerosis (ALS), but the molecular pathways leading to their formation remain incompletely understood. Oxidative stress associated with age, the major risk factor in ALS, contributes to this neurodegeneration in ALS. We show that several genes coding for enzymes of the ubiquitin and small ubiquitin-related modifier (SUMO) pathways exhibit altered expression in motor neuronal cells exposed to oxidative stress, such as the CCNF gene mutated in ALS patients. Eleven of these genes were further studied in conditions combining oxidative stress and the expression of an ALS related mutant of the superoxide dismutase 1 (SOD1) gene. We observed a combined effect of these two environmental and genetic factors on the expression of genes, such as Uhrf2, Rbx1, Kdm2b, Ube2d2, Xaf1, and Senp1. Overall, we identified dysregulations in the expression of enzymes of the ubiquitin and SUMO pathways that may be of interest to better understand the pathophysiology of ALS and to protect motor neurons from oxidative stress and genetic alterations.

Keywords: ALS; ubiquitin; SUMO; SOD1; oxidative stress

\section{Introduction}

Amyotrophic lateral sclerosis (ALS) is one of the most common adult-onset neurodegenerative diseases, caused by the selective death of motor neurons. A common feature in both sporadic ALS and familial ALS is the presence of protein aggregates rich in ubiquitin/ubiquitin-like proteins in motor neurons. These observations support a role for the ubiquitin proteasome system and ubiquitin-like small ubiquitin-related modifier (SUMO) system in ALS physiopathology [1-4].

Age is the major risk factor in the development of ALS [5]. Accumulative oxidative damages with age induce metabolic alterations, protein aggregation, and reduced mitochondrial function [6]. Oxidative damages are a consequence of an imbalance between a production of reactive oxygen species (ROS) and the ability of motor neurons/glial cells to reduce the level of ROS. Evidence of oxidative damages in ALS includes protein, lipid, and DNA oxidation observed in spinal cord and cerebrospinal fluid from ALS patients [7-11]. 
Current knowledge supports the involvement of interacting environmental and genetic factors in ALS. Superoxide dismutase 1 (SOD1) was the first gene identified in ALS [12]. More than 10\% of the familial forms of ALS are linked to mutations in the SOD1 gene $[13,14]$. The mechanisms by which mutant SOD1 proteins cause cell death in patients are still unclear. Various mechanisms have been suggested, such as participation of oxidative stress, abnormal protein aggregation rich in ubiquitin/ubiquitin-like proteins, and disrupted axonal transport and mitochondrial dysfunction [15-18].

We present an analysis of gene expression in motor neuronal-like cell line NSC-34 exposed to oxidative stress. We next focus on genes of the ubiquitin $(\mathrm{Ub}) / \mathrm{Ub}$-like pathways and study their expression in cells exposed to both oxidative stress and an ALS-linked SOD1 mutant protein.

\section{Results}

\subsection{Changes in Gene Expression in NSC-34 Cells Exposed to Oxidative Stress}

Oxidative stress has been shown to contribute to motor neuron injuries in ALS. We developed an in vitro model using the mouse motor neuronal cell line NSC-34 exposed to the microenvironmental stress hydrogen peroxide $\left(\mathrm{H}_{2} \mathrm{O}_{2}\right)$. NSC-34 cells exposed for $3 \mathrm{~h}$ to 0.1 or $1 \mathrm{mM} \mathrm{H}_{2} \mathrm{O}_{2}$ showed round-stressed shape without modification in cell viability (Figure 1A,B). Five hours after addition of 0.1 or $1 \mathrm{mM} \mathrm{H}_{2} \mathrm{O}_{2}$, a significant decrease in cell viability was observed (reduction by $18.3 \%$ and $28 \%$, respectively; $p<0.05$ ) (Figure $1 \mathrm{~A}$ ). We chose the $1 \mathrm{mM}$ $\mathrm{H}_{2} \mathrm{O}_{2}$ condition for $3 \mathrm{~h}$ for the following gene expression study by microarray analyses.
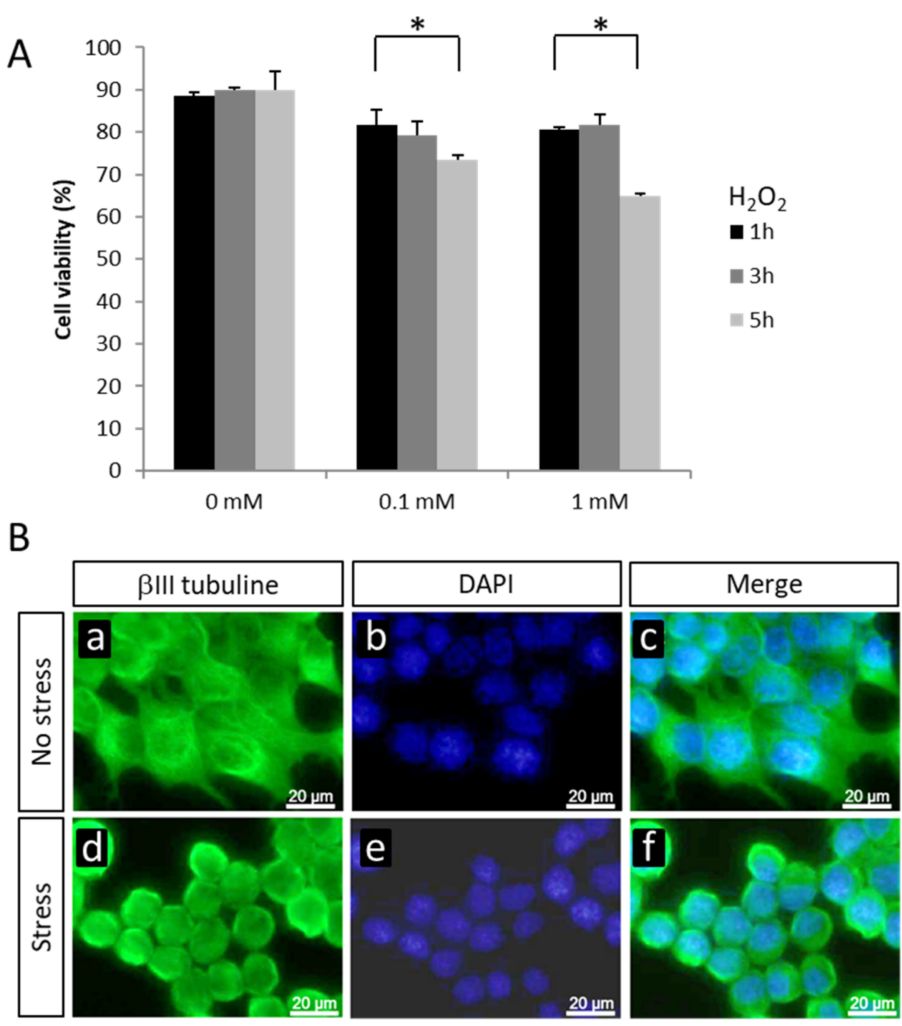

Figure 1. (A) Cell viability of non-transfected NSC-34 cells in absence or presence of 0.1 or $1 \mathrm{mM}$ $\mathrm{H}_{2} \mathrm{O}_{2}$ for 1,3 , or $5 \mathrm{~h}$. ${ }^{*} p<0.05$ nonparametric Mann-Whitney test. (B) Immunocytochemical visualization of $\beta$ III-tubulin in NSC-34 cells in absence $(\mathbf{a}, \mathbf{b}, \mathbf{c})$ or presence $(\mathbf{d}, \mathbf{e}, \mathbf{f})$ of $1 \mathrm{mM} \mathrm{H}_{2} \mathrm{O}_{2}$ for $3 \mathrm{~h}$. Scale bar: $20 \mu \mathrm{m}$.

Microarray analyses were performed with RNA samples from NSC-34 cell cultures expressing wild type human SOD1 in absence or presence of $1 \mathrm{mM} \mathrm{H}_{2} \mathrm{O}_{2}$ for $3 \mathrm{~h}$. We used SurePrint G3 Mouse GE $60 \mathrm{~K}$ arrays (Agilent, Santa Clara, CA, USA), which contain 
60,000 probes covering 39,430 Entrez gene RNAs and 16,251 long-noncoding RNAs (lcRNAs). Statistical analysis identified 360 probes associated with differentially expressed transcripts $(p<0.05)$ in cells exposed to oxidative stress, compared to cells cultured in normal condition. A total of 191 probes were linked to upregulated genes, and 169 probes to downregulated genes with $p$-value $<0.05$ and fold change $\geq 1.3$ (Table 1). Functional classification of the corresponding transcripts identified several biological pathways relevant in a context of neurodegenerative disease. These include cell response to DNA damage stimuli, apoptotic processes, antioxidant response, synaptic functions, mitochondrial function, and endosomal and Golgi functions. For example, we observed a decrease in expression of the cytotoxic granule associated RNA binding protein 1 (Tia1; fold change -2.83 ) whose implication in ALS pathology was recently supported by in vitro and in vivo studies [19]. We also described increase expression of methallothionein 1 (Mt1; fold change +7.51), previously studied in oxidative stress mechanisms and of interest in neurodegenerative diseases such as ALS [20,21].

Table 1. Pathways of interest with genes differentially expressed in NSC-34 expressing superoxide dismutase 1 wild type

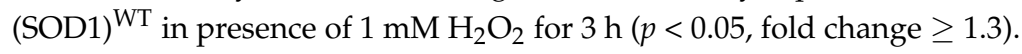

\begin{tabular}{|c|c|c|}
\hline Gene Symbol & Gene Name & Fold Change \\
\hline \multicolumn{3}{|c|}{ Cellular response to DNA damage stimulus } \\
\hline Cep164 & centrosomal protein 164 & -1.80 \\
\hline$E 2 f 7$ & E2F transcription factor 7 & -1.35 \\
\hline Ube $2 b$ & Ubiquitin-conjugating enzyme E2B & 1.31 \\
\hline$R b x 1$ & ring-box 1 & 1.35 \\
\hline Brip1 & BRCA1 interacting protein C-terminal helicase 1 & 1.36 \\
\hline Pcna & proliferating cell nuclear antigen & 1.37 \\
\hline Fancl & Fanconi anemia, complementation group L & 1.47 \\
\hline Gtf2h1 & general transcription factor II H, polypeptide 1 & 1.56 \\
\hline \multicolumn{3}{|l|}{ Apoptotic process } \\
\hline Myc & myelocytomatosis oncogene & -2.83 \\
\hline Tia1 & cytotoxic granule-associated RNA binding protein 1 & -2.53 \\
\hline Pde5a & phosphodiesterase $5 \mathrm{~A}$, cGMP-specific & -2.21 \\
\hline Mkl1 & MKL (megakaryoblastic leukemia)/myocardin-like 1 & -1.82 \\
\hline Bik & BCL2-interacting killer & -1.71 \\
\hline Dusp1 & dual specificity phosphatase 1 & -1.65 \\
\hline Pim1 & proviral integration site 1 & -1.46 \\
\hline Senp1 & SUMO1/sentrin specific peptidase 1 & -1.34 \\
\hline Ube $2 b$ & Ubiquitin-conjugating enzyme E2B & 1.31 \\
\hline $\operatorname{Tm} 2 d 1$ & TM2 domain containing 1 & 1.38 \\
\hline Birc5 & baculoviral IAP repeat-containing 5 & 1.41 \\
\hline Mad2l1 & MAD2 mitotic arrest deficient-like 1 & 1.43 \\
\hline$C f d p 1$ & craniofacial development protein 1 & 1.56 \\
\hline Cycs & cytochrome c, somatic & 1.58 \\
\hline Mt1 & metallothionein 1 & 7.51 \\
\hline \multicolumn{3}{|l|}{ Antioxidant response } \\
\hline Pdia2 & protein disulfide isomerase associated 2 & -2.71 \\
\hline Mtf1 & metal response element binding transcription factor 1 & -1.63 \\
\hline \multicolumn{3}{|l|}{ Synaptic functions } \\
\hline Sipa1l1 & signal-induced proliferation-associated 1 like 1 & -1.81 \\
\hline Btbd9 & BTB (POZ) domain containing 9 & -1.79 \\
\hline Apba1 & amyloid beta (A4) precursor protein binding. family $\mathrm{A}$, member 1 & -1.79 \\
\hline Nat8l & $\mathrm{N}$-acetyltransferase 8-like & -1.65 \\
\hline Pacsin1 & protein kinase $C$ and casein kinase substrate in neurons 1 & -1.34 \\
\hline Paip2 & polyadenylate-binding protein-interacting protein 2 & 1.55 \\
\hline Cnn3 & calponin 3 , acidic & 2.25 \\
\hline
\end{tabular}


Table 1. Cont.

\begin{tabular}{llc}
\hline \multicolumn{1}{c}{ Gene Symbol } & Gene Name & Fold Change \\
\hline Mitochondrial function & & -1.71 \\
Bik & BCL2-interacting killer & -1.43 \\
Alas1 & aminolevulinic acid synthase 1 & 1.32 \\
Slmo2 & slowmo homolog 2 (Drosophila) & 1.35 \\
Trit1 & tRNA isopentenyltransferase 1 $1 D$ (mitochondrial) & 1.36 \\
Metap1d & methionyl aminopeptidase type 1D & 1.38 \\
Lypla1 & lysophospholipase 1 & 1.38 \\
Hibadh & 3-hydroxyisobutyrate dehydrogenase & 1.41 \\
Mrpl9 & mitochondrial ribosomal protein L9 & 1.42 \\
Pgam5 & phosphoglycerate mutase family member 5 & 1.49 \\
Timm8a1 & translocase of inner mitochondrial membrane 8A1 & 1.54 \\
Ndufab1 & NADH dehydrogenase (ubiquinone) 1, alpha/beta subcomplex, 1 & 2.03 \\
Lyrm7 & LYR motif containing 7 & -1.53 \\
Endosome and golgi functions & & -1.35 \\
Adcy6 & adenylate cyclase 6 & 1.33 \\
Rab21 & RAB21, member RAS oncogene family & 1.50 \\
Rab9 & RAB9, member RAS oncogene family & 1.52 \\
Pmel & premelanosome protein & \\
\hline
\end{tabular}

\subsection{Gene Expression Variations in the Ubiquitin/Ubiquitin-like Pathways}

The analysis of microarray data pointed out an enrichment in genes of the ubiquitin $(\mathrm{Ub}) / \mathrm{Ub}$-like pathways $(p<0.05)$. To accurately identify all differentially expressed genes of these pathways in our data, we first created a list of all genes known to be implicated in these pathways by combining data from the databases Kyoto Encyclopedia of Genes and Genomes (KEGG), Ensembl, DUDEdb, and the literature [22]. We generated a list of 729 genes, with a majority of E2 conjugating enzymes, E3 ligases, and peptidases. Using this list, we reanalyzed the microarray data and identified 24 genes of the $\mathrm{Ub} / \mathrm{Ub}$-like pathways differentially expressed (fold change $\geq 1.3$ ) in NSC-34 exposed to stress vs. cultured in normal condition. These genes are presented in Table 2 according to their enzymatic function. We found an increased expression of 10 genes, such as E2 Ube2r2, Ube2c, and E3 Fancl, Uhrf2, Rnf121. We observed a decreased expression for 14 genes, such as E2 Ube2d1, E3 CCNF, Trim9, and Rnf31, and SUMO1/sentrin-specific peptidase 1 (SENP1). Interestingly, mutations in the CCNF gene were recently observed in ALS patients [23].

Table 2. Gene of the ubiquitin $(\mathrm{Ub}) / \mathrm{Ub}$-like family differentially expressed in NSC-34 expressing SOD ${ }^{\mathrm{WT}}$ in presence of $1 \mathrm{mM} \mathrm{H}_{2} \mathrm{O}_{2}$ for $3 \mathrm{~h}(p<0.05$, fold change $\geq 1.3$ ).

\begin{tabular}{|c|c|c|}
\hline Gene Symbol & Gene Name & Fold Change \\
\hline \multicolumn{3}{|c|}{ E2 conjugating enzymes } \\
\hline Ube2d1 & Ubiquitin-conjugating enzyme E2D1 & -1.87 \\
\hline Ube $2 d 2$ & Ubiquitin-conjugating enzyme E2D2 & 1.30 \\
\hline Ube $2 b$ & Ubiquitin-conjugating enzyme E2B & 1.31 \\
\hline Ube2e1 & Ubiquitin-conjugating enzyme E2E1 & 1.37 \\
\hline Ube $2 c$ & Ubiquitin-conjugating enzyme E2C & 1.39 \\
\hline \multicolumn{3}{|l|}{ E3 ligases } \\
\hline \multicolumn{3}{|c|}{ E3 ligases with multipled subunits with RING domain } \\
\hline \multicolumn{3}{|c|}{ Subunits with RING domain } \\
\hline$R b x 1$ & Ring-box 1 & 1.35 \\
\hline \multicolumn{3}{|c|}{ Subunits (adaptators) } \\
\hline CCNF & Cyclin F baisse & -2.44 \\
\hline Spsb4 & SpIA/ryanodine receptor domain and SOCS box containing 4 & -1.92 \\
\hline
\end{tabular}


Table 2. Cont.

\begin{tabular}{lll}
\hline Gene Symbol & \multicolumn{1}{c}{ Gene Name } & Fold Change \\
\hline Btbd9 & BTB (POZ) domain containing 9 & -1.78 \\
Klhl29 & Kelch-like 29 (Drosophila) & -1.61 \\
Fbxo46 & F-box protein 46 & -1.54 \\
Rhobtb2 & Rho-related BTB domain containing 2 & -1.43 \\
Klhl21 & Kelch-like 21 (Drosophila) & -1.33 \\
Fbxo42 & F-box protein 42 & -1.26 \\
Cdc16 & CDC16 cell division cycle 16 homolog (S.cerevisiae) & 1.30 \\
Zbtb32 & Zinc finger and BTB domain containing 32 & 1.41 \\
other E3 ligases & & \\
Trim9 & Tripartite motif-containing 9, transcript variant 3 & -2.27 \\
Sh3rf1 & SH3 domain containing RING finger 1 & -1.95 \\
Rnf121 & RING finger protein 121 & 1.35 \\
Fancl & Fanconi anemia, complementation group L & 1.46 \\
Uhrf2 & Ubiquitin-like, containing PHD and RING finger domains 2 & 1.49 \\
Others & & -2.25 \\
Usp44 & Ubiquitin specific peptidase 44 & -1.70 \\
Usp36 & Ubiquitin specific peptidase 36 & -1.34 \\
Senp1 & SUMO1/sentrin specific peptidase 1 & \\
\hline
\end{tabular}

\subsection{Combined Effect of Oxidative Stress and Mutant SOD $1^{A 4 V}$}

To go a step forward to model the molecular mechanisms of motor neuron injury in ALS, we next investigated changes in gene expression in the $\mathrm{Ub} / \mathrm{Ub}$-like pathways induced by a combined action of oxidative stress and ALS-related SOD1 mutation. Based on knowledge in the literature, i.e., participation in stress responses and in other mechanisms implicated in neurodegenerative diseases, such as endoplasmic reticulum (ER) stress response, apoptosis, or mitophagy, we selected six out of the 24 genes of these pathways identified by our microarray analysis. These genes were Ube2e1, Ube2d2, Trim9, Uhrf2, $\mathrm{Rbx1}$, and Senp1. We also reanalyzed our microarray data searching for genes of the $\mathrm{Ub} / \mathrm{Ub}$-like pathways close to significance in a context of oxidative stress $(0.05 \leq p<0.06)$. We hypothesized that some of these genes may reach significance when combining oxidative stress and genetic mutations, such as SOD1 mutation. We selected five genes in this list, based on knowledge of functions in the literature, i.e., Ube3b, Birc3, Xaf1, Kdm2b, and Siah2.

These 11 genes of the $\mathrm{Ub} / \mathrm{Ub}$-like pathways were analyzed by RT-qPCR in cultures of NSC-34 exposed to $1 \mathrm{mM} \mathrm{H} \mathrm{H}_{2}$ for $3 \mathrm{~h}$ and expressing the protein SOD1 ${ }^{\mathrm{WT}}$-GFP or the ALS-related mutant SOD1 ${ }^{\mathrm{A} 4 \mathrm{~V}}$-GFP. At time of exposure to oxidative stress, NSC-34 expressing SOD $1^{\mathrm{A} 4 \mathrm{~V}}$ for $48 \mathrm{~h}$ showed GFP positive aggregates in the cytoplasm (Figure 2). A combined effect of the ALS-related microenvironmental factor oxidative stress and an ALS-related genetic factor mutant $\mathrm{SOD} 1^{\mathrm{A} 4 \mathrm{~V}}$ affected significatively the expression of six out of the 11 genes selected in the $\mathrm{Ub} / \mathrm{Ub}$-like pathways (Figure 2). In a context of oxidative stress, NSC-34 expressing SOD1 ${ }^{\mathrm{A} 4 \mathrm{~V}}$ showed a significant increased expression of the E2 Ube2d2, the E3 Rbx1, Uhrf2, Kdm2b, and the peptidase Senp1 ( $p<0.05)$. In contrast, the expression of Xaf1, an inhibitor of inhibitors of apoptosis proteins (IAPs), was significantly reduced $(p<0.05)$ [24]. 

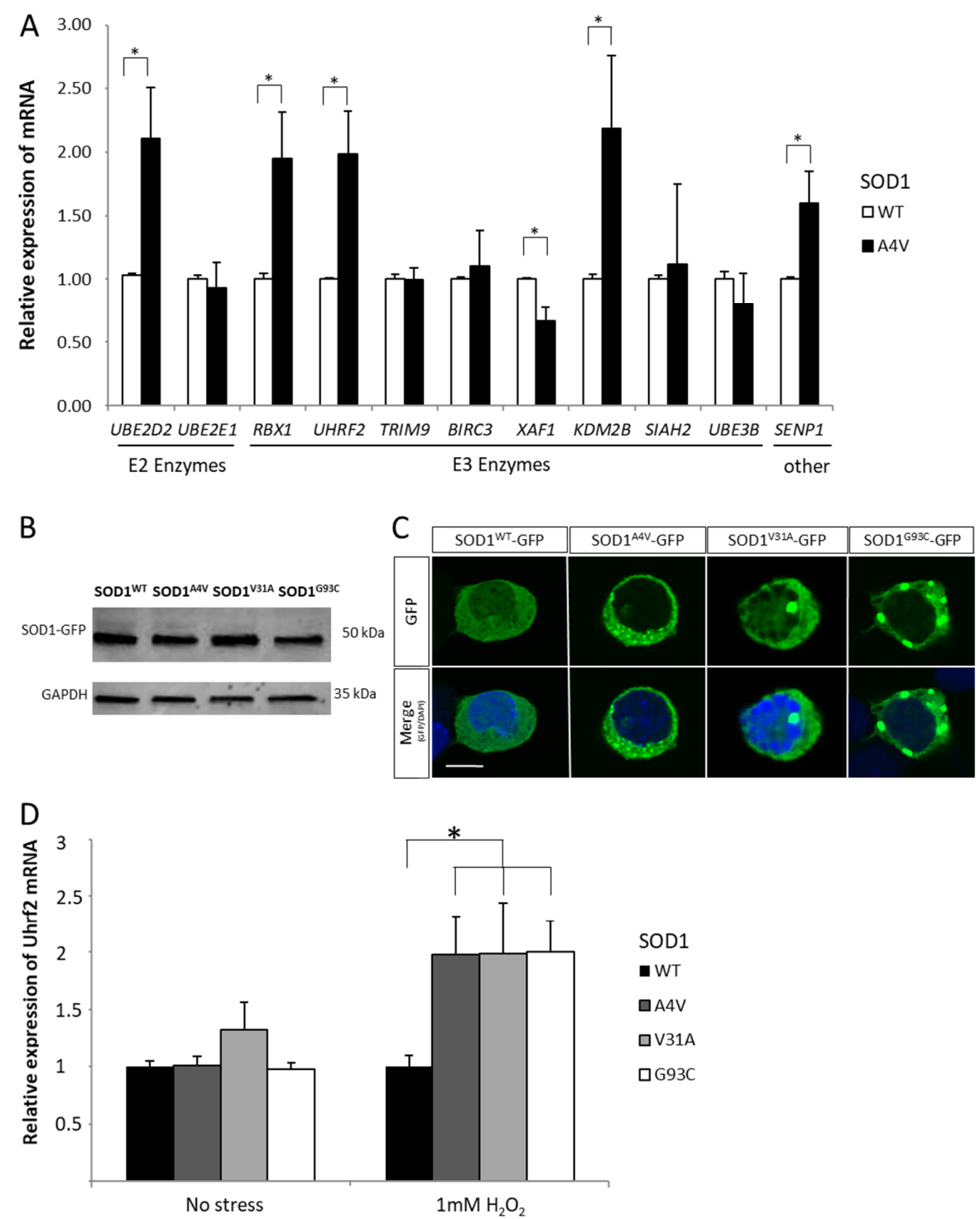

Figure 2. (A) Relative mRNA expression of Ube2d2, Ube2e1, Rbx1, Uhrf2, Trim9, Birc3, Xaf1, Kdm2b, Siah2, Ube3b, and Senp1 in NSC-34 cells expressing SOD1 ${ }^{\mathrm{WT}}$ or SOD1 ${ }^{\mathrm{A} 4 \mathrm{~V}}$ in presence of $1 \mathrm{mM}$ of $\mathrm{H}_{2} \mathrm{O}_{2}$ for $3 \mathrm{~h}$. (B) Western blotting of SOD1-GFP proteins in NSC-34 cells expressing SOD1 ${ }^{\text {WT }}$-GFP, SOD1 ${ }^{\text {A4V }}$-GFP, SOD1 ${ }^{\text {V31A }}$-GFP, and SOD1 ${ }^{\text {G93C_GFP }}$ using antibodies against GFP or Gapdh. (C) Confocal microscopy analysis of SOD1 ${ }^{\text {WT }}$-GFP or SOD1 ${ }^{\text {mutant }}$-GFP in NSC-34 showing aggregates (48 h post-transfection). Scale bar: $30 \mu \mathrm{m}$. (D) Relative mRNA expression of Uhr2 in NSC-34 cells expressing SOD1 ${ }^{\mathrm{WT}}$, SOD1 ${ }^{\mathrm{A} 4 \mathrm{~V}}$, SOD1 ${ }^{\mathrm{V} 31 \mathrm{~A}}$, and SOD1 ${ }^{\mathrm{G} 93 \mathrm{C}}$ in absence or presence of $1 \mathrm{mM}$ of $\mathrm{H}_{2} \mathrm{O}_{2}$ for $3 \mathrm{~h} .{ }^{*} p<0.05$.

\subsection{Variation of Expression of the E3 Ligase Uhrf2 in Presence of SOD1 Mutants}

To examine a possible participation of these differentially-expressed genes of the $\mathrm{Ub} / \mathrm{Ub}$-like pathway in motor neuron degeneration, we analyzed the consequence of the expression of various SOD1 mutants on one of these genes, the E3 ligase ubiquitin-like with PHD and RING finger domains 2 (Uhrf2), also known as Np95/ICBP90-like RING finger (NIRF). We focused on Uhrf2, a nuclear protein, because it is expressed in many regions of the CNS, including cortex, and it has been implicated in other neurodegenerative diseases with aggregate formation [25-27].

We first analyzed the effect of three ALS-related pathogenic SOD1 mutations (SOD1 ${ }^{\mathrm{A} 4 \mathrm{~V}}$, $\mathrm{SOD} 1^{\mathrm{V} 31 \mathrm{~A}}$, and $\mathrm{SOD} 1^{\mathrm{G} 93 \mathrm{C}}$ ) on Uhrf2 gene expression. The three mutant SOD1s induced the formation of aggregates (Figure 2B,C) and an upregulation of Uhrf2 expression (Figure 2D). Uhrf2 protein was mainly nuclear (Figure $3 \mathrm{~A}$ ) and did not colocalize with SOD1 ${ }^{\mathrm{G} 93 \mathrm{C}}$-GFP positive aggregates (Figure 3B, supplementary Figure S1A,B). We next examined the effect 
of siRNA-mediated reduction of Uhrf2 expression in NSC-34 cells expressing SOD1 ${ }^{\mathrm{G} 93 \mathrm{C}}$ GFP for $24 \mathrm{~h}$ and exposed to oxidative stress for $3 \mathrm{~h}\left(1 \mathrm{mM} \mathrm{H}_{2} \mathrm{O}_{2}\right)$ (Figure 3C). Uhrf2 binds to the promoter of the proapoptotic gene Siva in the U2OS osteosarcoma cell line [28]. In our model, siRNA-mediated reduction of Uhrf2 expression resulted in a significant decrease $(37.6 \%)$ of Siva gene expression (Figure 3D). These data support a possible role of Uhrf2 in motor neuron degeneration observed in a context of ALS combining environmental and genetic factors.

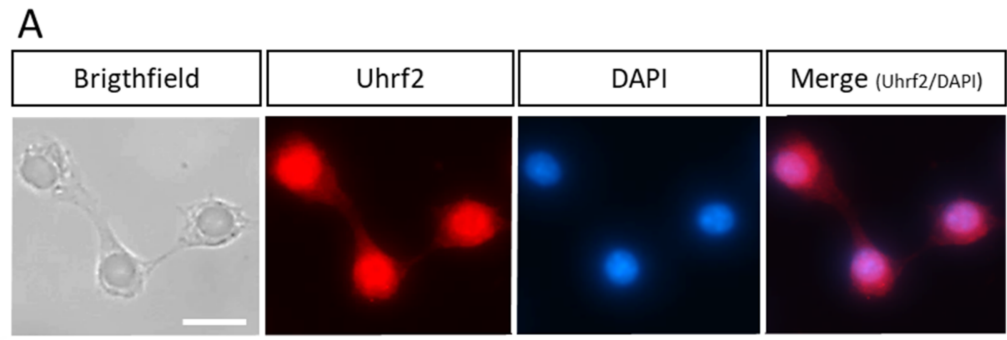

B

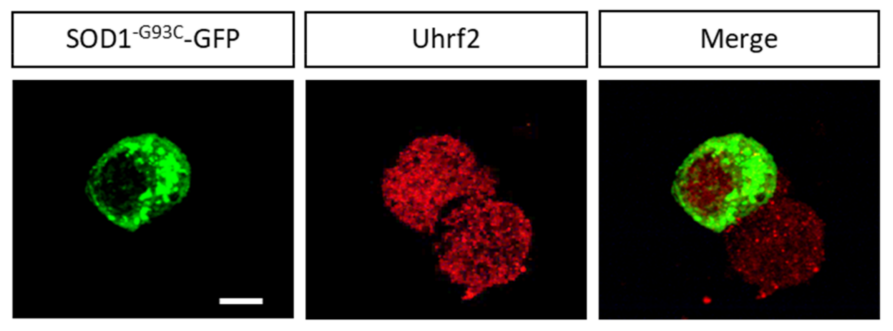

C

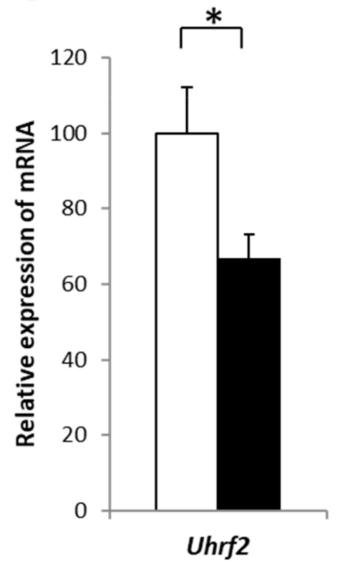

D

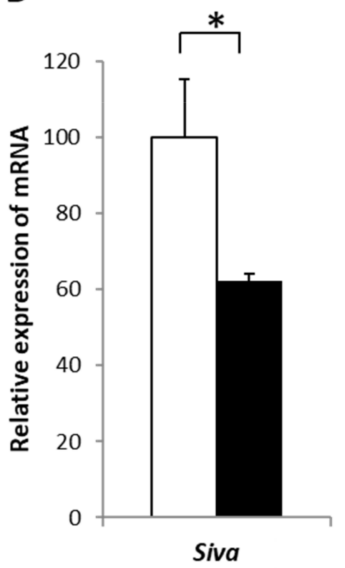

Figure 3. (A) Immunocytochemical visualization of Uhrf2 in NSC34 cells. (B) Absence of colocalization of SOD1 ${ }^{\mathrm{G} 93 \mathrm{C}}$-GFP proteins with Uhrf2 in aggregates observed by confocal microscopy analysis. Scale bar: $10 \mu \mathrm{m}$. (C) Relative mRNA expression of Uhrf2 (RT-qPCR analysis) in NSC-34 cells coexpressing SOD1 ${ }^{\mathrm{G} 93 \mathrm{C}}$-GFP and anti-Uhrf2 siRNA (or control siRNA) in presence of $1 \mathrm{mM}$ of $\mathrm{H}_{2} \mathrm{O}_{2}$ for $3 \mathrm{~h}$. (D) Relative mRNA expression of Siva in NSC-34 cells coexpressing SOD1 ${ }^{\mathrm{G} 93 \mathrm{C}}$-GFP and siRNA anti-Uhrf2 (or siRNA control) in presence of $1 \mathrm{mM}$ of $\mathrm{H}_{2} \mathrm{O}_{2}$ for $3 \mathrm{~h}(n=3){ }^{*} p<0.05$.

\section{Discussion}

The present study was designed to analyze variations in gene expression that follow the exposure of NSC-34 cells, a motor neuronal cell line, to oxidative stress and to an ALSrelated SOD1 mutant. A particular focus was given to members of the ubiquitin/ubiquitinlike systems $[29,30]$.

We first investigated changes in global gene expression in NSC-34 cells exposed to oxidative stress. We chose to use NSC-34 cells because it is the most common cell line used 
in ALS research and it was described as having several morphological and physiological properties of motor neurons [31]. Moreover, NSC-34 cells allow high transfection rates, which is more difficult to obtain with other neuronal cell lines or primary cultures of neurons. However, these NSC-34 cultures are not primary cultures and are not in a glial environment, so the results will need to be confirmed in vivo. They represent a model of interest to investigate the mechanisms of motor neuron degeneration in ALS because they are not contaminated by astrocytes or other glial cells responsible for dilution effects in neuronal gene expression studies. Nevertheless, glial cells, and particularly astrocytes, are implicated in ALS pathogenesis, and thus their absence is a limit of our model. We obtained by microarray analysis a list of genes which, for some of them, have functions of interest in a context of neurodegenerative disease. A decrease in expression of T-cell intracellular antigen-1 (TIA-1) was observed. Tia1 is an mRNA binding protein that induces the formation of stress granules in the cytoplasm during cell stress [32]. It is a major component of stress granules, and similarly to other proteins located in stress granules, such as TDP-43, FUS, SMN1/2, and ATXN2, it could be of particular importance in ALS. Interestingly, immunoprecipitation experiments in NSC-34 cells showed that Tia-1 interacts directly with mutant SOD1 [19]. Increase in expression of methallothionein 1 (MT-1) was also observed. This is of particular interest because a recent study reported that overexpression of MT-1 extends lifespan in a mouse model of amyotrophic lateral sclerosis caused by mutant SOD1 [33]. MT-1 is one of the two major isoforms of MTs that exert neuroprotection against copper dyshomeostasis [34].

Interestingly we observed an enrichment of genes of the ubiquitin $(\mathrm{Ub}) / \mathrm{Ub}$-like pathways in our list of differentially expressed genes. Trim9 was one of the genes showing an important decrease in expression when motor neuronal cells were exposed to oxidative stress. The expression of this brain-specific E3 ubiquitin ligase Trim9 is decreased in aged mice, and is repressed in affected brain areas of Lewy body disease [35,36]. The expression of Ube2d2 (also known as UbcH5d), the E2 conjugating enzyme collaborating with the E3 Trim9, was also affected when NSC-34 were exposed to oxidative stress. The only function known for Trim9 is a ligase activity promoting SNARE-mediated vesicle fusion and axon branching [37]. SNARE-dependent exocytose participates in SOD1 ${ }^{\mathrm{G} 93 \mathrm{~A}}$ astrocytesmediated toxicity in ALS [38]. On the contrary, Rbx1 gene was one of the genes showing an increase of expression during oxidative stress. It encodes the RING-box protein, a member of the SCF ubiquitin ligase complex controlling the degradation of the transcription factor nuclear factor-like 2 (Nrf2) in cells in basal conditions. In response to oxidative stress, Nrf2 translocates to the nucleus, controls the expression of a series of genes encoding detoxifying enzymes, anti-apoptotic proteins, and proteasomal proteins, and then is exported outside the nucleus for degradation [39]. Several studies support that NRF2 activation has a protective role against oxidative stress and cell death promoted by SOD1 mutations [40,41]. We also observed an increase of expression of Ube2r2 and Fancl, two genes of the $\mathrm{Ub}$ pathway implicated in the Wnt/ $\beta$-catenin pathway. Accumulating evidence indicated that dysregulation of $\mathrm{Wnt} / \beta$-catenin signaling is associated with neurodegenerative disorders [42]. A recent study showed that NSC-34 cells expressing mutated SOD1 show modifications of transcriptional activity associated with the Wnt/ $\beta$-catenin pathway [43]. It is also very interesting to note that exposure of NSC-34 to oxidative stress modifies the expression of the CCNF gene encoding cyclin-F, which has recently been shown to be mutated in ALS patients [23]. CCNF could affect the activity of the VCP protein in the cytoplasm and participate in the formation of TDP-43 positive aggregates in patients when it is mutated [44].

Combined effects of microenvironmental factors such as oxidative stress and genetics factors such as mutation in SOD1 gene are highly suspected in the development of ALS. Based on our results, we decided to focus on genes of the $\mathrm{Ub} / \mathrm{Ub}$-like pathways, and particularly on 11 genes out of the 729 genes of the Ub/SUMO pathways. We selected three mutants, SOD1 A4V, G93C, and V31A, because they have all been reported in the literature (dominant mutations), are mutated at different positions in the protein SOD1, and are 
all associated with the formation of protein aggregates [45-47]. A4V is a mutant causing a rapidly progressive form of the disease, so we chose this mutant for RT-qPCR studies. We then selected G93C and V31A, two mutants associated with slower progressive forms of the disease. We first expressed the ALS-related mutant SOD1 ${ }^{\mathrm{A} 4 \mathrm{~V}}$ in NSC-34 cells and exposed these cells to $1 \mathrm{mM} \mathrm{H}_{2} \mathrm{O}_{2}$. We observed a combined effect on the expression of six genes encoding a E2 enzyme, four E3 enzymes, and one peptidase SENP. Some of them, the ubiquitin-E2, Ube2d2, and the SUMO-peptidase Senp1, can be directly linked to p53 activation, which plays a major role in the pathological process of motor neuron death in ALS [48-51]. In contrast to previous studies on spinal cord or primary cortical neurons from transgenic SOD1 ${ }^{\mathrm{G} 93 \mathrm{~A}}$ mice, we did not observe in our in vitro model an increase of expression of Ube2i, the unique E2 enzyme of the SUMO pathway [52,53]. This increase of expression of Ube2i could result from changes of expression in astrocytes present in these two models, and not in motor neurons. Glial cells were absent in our cultures [53].

The ubiquitin-like with PHD and RING finger domains 2 (Uhrf2) is another gene of interest. Also called Nirf (Np95/ICBP90-like RING finger), it encodes a ubiquitin-E3 ligase expressed in human brain [26]. UHRF2 is required for the proapoptotic activity of E2F1 transcription factor, as well as for the transcription of several genes encoding regulators of apoptosis [28]. Interestingly, a recent study showed that UHRF2 is also a SUMO-E3 ligase implicated in the SUMOylation of the transcription factor zinc finger protein 131 (ZNF131) highly expressed in the central nervous system and whose activation could have neuroprotective effect on motor neurons [54-56]. We showed that siRNA against Uhrf2 expression reduced the expression of Siva, an apoptosis-selective p53 target gene implicated in cell death [57]. Further studies will be necessary to show its direct involvement in ALS.

In summary, this gene expression study supports the idea that dysregulations in the $\mathrm{Ub} / \mathrm{SUMO}$ pathways could affect protective mechanisms and trigger cell death mechanisms responsible for motor neuron degeneration in ALS. To our knowledge, this is the first global gene expression study that has attempted to analyze changes in these pathways in motor neuronal cells combining microenvironmental oxidative stress and ALS-related mutations in SOD1 gene. We showed additive effects of the oxidative stress and SOD1 mutations for particular genes of the Ub/SUMO pathways. We identified several genes of interest for further analysis through genetic studies in ALS populations or functional studies to identify new causative genes, or protective or risk factors for ALS.

\section{Methods}

\subsection{Cell Cultures}

NSC-34 cells were cultured at $37{ }^{\circ} \mathrm{C}$ in a $5 \% \mathrm{CO}_{2}$ incubator in DMEM containing $25 \mathrm{mmol} / \mathrm{L}$ glucose, $0.58 \mathrm{~g} / \mathrm{L}$ L-glutamine and $10 \%$ fetal bovine serum, $100 \mathrm{U} / \mathrm{mL}$ penicillin, and $100 \mu \mathrm{g} / \mathrm{mL}$ streptomycin (Sigma-Aldrich ${ }^{\circledR}$, St. Louis, MO, USA). For oxidative stress conditions, cultures were treated with various concentrations of $\mathrm{H}_{2} \mathrm{O}_{2}$ for 1,3 , or $5 \mathrm{~h}$.

\subsection{Cell Viability Assay}

For the Trypan blue assay, $48 \mathrm{~h}$ post-transfection the cells were trypsinized and centrifuged for $5 \mathrm{~min}$ at $2500 \times \mathrm{g}$ and resuspended in DMEM, before addition of Trypan blue $(0.4 \% w / v)$ (Molecular Probes-Invitrogen, Carlsbad, CA, USA). Living and dead cells were accurately counted by a Countess Automated Cell Counter (Invitrogen, Carlsbad, CA, USA).

\subsection{Microarray Experiments}

Total RNAs of NSC-34 cell line cultures were prepared using TRIzol ${ }^{\circledR}$ extraction method (Invitrogen) and further purified using the RNeasy Micro Kit (Qiagen, Hilden, Germany). RNA quality was assessed by ND-1000 spectrophotometry (NanoDrop Technologies, Wilmington, DE, USA). Samples from four biological replicates of NSC-34 cell line transfected with human SOD $1^{\mathrm{WT}}$ plasmid and cultured in absence or presence of $1 \mathrm{mM}$ $\mathrm{H}_{2} \mathrm{O}_{2}$ for $3 \mathrm{~h}$ were hybridized on SurePrint G3 Mouse GE $8 \times 60 \mathrm{~K}$ Microarrays (Agilent). 
The one-color microarray-based gene expression analysis protocol (version 5.7 of the One-Color Microarray-Based Gene Expression Analysis) was used to construct and to fluorescently label cRNA from total RNA extracts. Briefly, probes were prepared by converting an aliquot of $100 \mathrm{ng}$ total RNA from each sample into labeled cRNA, using reagents from the one-color spike-in kit (Agilent Technologies) and one-color Quick amp labeling kit (catalogue No.5190-0442, Agilent Technologies). Total RNA were reverse transcribed into first and second-strand cDNA, after which first-strand cRNA were synthesized using the second-strand cDNA as a template in the presence of Cy3-CTP. Labeled cRNA were purified using the RNeasy mini spin column kit (Qiagen). Labeling efficiency was determined at $550 \mathrm{~nm}$ (Cy3) by ND-1000 spectrophotometry (NanoDrop Technologies).

Then, 800 ng Cy3-labelled cRNA were hybridized on individual $60 \mathrm{~K}$ arrays for $17 \mathrm{~h}$ at $65{ }^{\circ} \mathrm{C}$. After hybridization, arrays were washed with Gene Expression Wash Buffers 1 and 2 (Agilent). Slides were scanned immediately following washing in the Agilent Scanner (SureScan, Plano, TX, USA) using Scan Control 9.1.7.1 software. The scan resolution was $3 \mu \mathrm{m}$. Scan data were extracted with Feature Extraction 10.7.3.1 software using the GE1_107 _Sep09 protocol. Extracted signal intensities were analyzed using GeneSpring 12.0 software (Agilent) and the datasets were normalized using standard Agilent FE Import 1-color settings. Genes were tested for differential expression using student tests, and $p$-values were corrected for multiple testing Benjamini and Hochberg; FDR 0.05. Analysis of cellular pathways was done using The Database for Annotation, Visualization and Integrated Discovery (DAVID) v6.7 [58].

\subsection{Expression Vectors and Transfections}

Full-length human wild type SOD1 cDNA was obtained using reverse transcription polymerase chain reaction on total RNA from leukocytes of a normal human individual, before insertion into pcDNA6.2/C-EmGFP-Gw/TOPO (Invitrogen, Carlsbad, CA, USA). Plasmids were amplified in TOP10 Escherichia coli bacteria, purified, and sequenced. Three ALS-related SOD1 mutants were generated by site-directed mutagenesis; SOD1 ${ }^{\mathrm{A} 4 \mathrm{~V}}$, SOD1 ${ }^{\mathrm{V} 31 \mathrm{~A}}$, and SOD1 ${ }^{\mathrm{G} 93 \mathrm{C}}[45,46,59]$. A total of $24 \mathrm{~h}$ after plating NSC-34 cells on polyD-lysine coated surface $(25 \mu \mathrm{g} / \mathrm{mL})$, transfection of cells by plasmids $(1.6 \mu \mathrm{g})$ or siRNA $\left(1.6 \mu \mathrm{g}\right.$, Silencer ${ }^{\circledR}$ Select anti-Uhrf2, s99417; Silencer Select negative control, Ambion $\left.{ }^{\circledR}\right)$ was conducted with Lipofectamine 2000 according to manufacturer's instructions (Invitrogen).

\subsection{Western Blot Analysis}

NSC-34 cells were lysed in Radio Immunoprecipitation Assay (RIPA) (ThermoFisher) buffer with protease inhibitors (Halt Protease Inhibitor Cocktail, Thermo Scientific). Then, $30 \mu \mathrm{g}$ of proteins were separated by SDS-PAGE in a 4-15\% polyacrylamide gel and transferred to a polyvinylidene fluoride (PVDF) membrane. The membrane was treated with $5 \%$ of milk in Tris-buffer containing $0.1 \%$ Tween-20 before overnight incubation at $4{ }^{\circ} \mathrm{C}$ with a polyclonal goat anti-GFP antibody (sc-5385, 1/200 Santa Cruz Biotechnology ${ }^{\circledR}$ Inc., Dallas, TX, USA). Horseradish peroxydase-conjugated rabbit anti-goat antibody (81-1620, 1/2500, Zymed, South San Francisco, CA, USA) was used as secondary antibody before chemiluminescence analysis using ECL (Pierce-Thermo Fischer Scientific Inc., Rockford, IL, USA) and quantification by QuantityOne software (BioRad, Hercules, CA, USA). GAPDH expression was used for normalization using polyclonal goat anti-GAPDH antibody (sc-48166, 1/250, Santa Cruz Biotechnology Inc.) and secondary donkey anti-goat antibody (V8051, 1/2500, Promega, Madison, WI, USA).

\subsection{Immunocytochemical Analysis}

Cells were fixed with $4 \%$ paraformaldehyde (Sigma-Aldrich ${ }^{\circledR}$ ) in phosphate buffer saline (PBS) for $45 \mathrm{~min}$ at room temperature (RT). After $1 \mathrm{~h}$ at RT in $1 \%$ bovine serum albumin, 5\% horse serum, and $0.2 \%$ triton $\mathrm{X}-100$ in PBS, cells were incubated overnight at $4{ }^{\circ} \mathrm{C}$ with mouse polyclonal antibody against $\beta$-3-tubulin (1:200, PRB-435P, Covance, Princeton, NJ, USA), or a polyclonal goat anti-UHRF2 antibody (1:200, sc-54252, Santa Cruz 
Biotechnology ${ }^{\circledR}$ Inc.). This was followed by an incubation of $1 \mathrm{~h}$ at RT with FITC labeled antibody against mouse IgG (Jackson Immuno Research, West Grove, PA, USA, 115-095-205) or Fluoprobes 594 Donkey antibody against goat IgG (Interchim FP-SD2110). Preparations were mounted with Prolong Gold Antifade (Invitrogen ${ }^{\mathrm{TM}}$ ) and observed under AMG Evos F1 microscope or Olympus Fluoview 500 confocal laser scanning microscope.

\subsection{RT-qPCR Analysis}

Total RNA were extracted from NSC-34 cells $48 \mathrm{~h}$ after transfection by plasmid expressing SOD $1^{\mathrm{WT}}$ or SOD1 $1^{\text {mutant }}$, using Trizol (Invitrogen). Then, $1 \mu \mathrm{g}$ RNA were treated with 1 $\mu \mathrm{L}$ RNase-free DNase I (Invitrogen). cDNA were synthesized using the SuperScript ${ }^{\mathrm{TM}} \mathrm{II}$ RT kit (Invitrogen), and qPCR was performed using $50 \mathrm{ng}$ cDNA as template with SsoAdvanced $^{\mathrm{TM}}$ SYBR ${ }^{\circledR}$ Green Supermix (BioRad) reagent. Samples from four biological replicates were analyzed in duplicate in a LightCycler480 (Roche, Basel, Switzerland). The $2^{-\Delta \Delta C p}$ method was used for quantifications. Normalized ratios were obtained for each target gene using the LC480 software (qPCR efficiencies for each gene were used), and beta-actin and Gapdh as normalization genes.

\subsection{Statistical Analysis}

Genespring (Agilent) and Excel software were used for statistical analysis. Data are presented as mean + - standard errors of the mean (SEM) of four independent experiments. Statistical analysis was performed using Student tests, and the non-parametric MannWhitney or Kruskall-Wallis tests.

Supplementary Materials: The following are available online at https:/ /www.mdpi.com/1422-006 7/22/4/1796/s1, Figure S1: (A) Localization of Uhrf2 protein in NSC-34 cells expressing SOD1 ${ }^{\mathrm{WT}}$ $\operatorname{GFP}(a, b)$ or SOD1 ${ }^{\mathrm{G} 93 C_{-}}$GFP $(c, d)$, in absence $(a-c)$ or presence $(b-d)$ of $1 \mathrm{mM}^{-} \mathrm{H}_{2} \mathrm{O}_{2}$ during 3 hours. Scale bar: $50 \mu \mathrm{m}$ (B) Control goat IgG antibody. Scale bar: $50 \mu \mathrm{m}$

Author Contributions: Conceptualization, A.D. and P.V.; Data curation, F.W. and C.B.; Formal analysis, A.D., S.M., R.C., F.W. and C.B.; Investigation, F.L., P.C., C.R.A. and H.B.; Methodology, S.M. and R.C.; Validation, S.H.; Writing—original draft, A.D., S.H. and P.V.; Writing-review \& editing, F.L., P.C., C.R.A., H.B., P.V. All authors have read and agreed to the published version of the manuscript.

Funding: This research received no external funding.

Informed Consent Statement: Not applicable.

Acknowledgments: We would like to thank the Department of Genomics and Department of Microscopy of the Platform ASB of the Universite de Tours, Tours. A.D. was supported by a Region Centre fellowship.

Conflicts of Interest: The authors declare no actual or potential conflict of interest.

\section{References}

1. Bendotti, C.; Marino, M.; Cheroni, C.; Fontana, E.; Crippa, V.; Poletti, A.; De Biasi, S. Dysfunction of constitutive and inducible ubiquitin-proteasome system in amyotrophic lateral sclerosis: Implication for protein aggregation and immune response. Prog. Neurobiol. 2012, 97, 101-126. [CrossRef]

2. Ciechanover, A.; Kwon, Y.T. Degradation of misfolded proteins in neurodegenerative diseases: Therapeutic targets and strategies. Exp. Mol. Med. 2015, 47, e147. [CrossRef]

3. Dangoumau, A.; Veyrat-Durebex, C.; Blasco, H.; Praline, J.; Corcia, P.; Andres, C.R.; Vourc'H, P. Protein SUMOylation, an emerging pathway in amyotrophic lateral sclerosis. Int. J. Neurosci. 2013, 123, 366-374. [CrossRef]

4. Maurel, C.; Dangoumau, A.; Marouillat, S.; Brulard, C.; Chami, A.; Hergesheimer, R.; Corcia, P.; Blasco, H.; Andres, C.R.; Vourc'H, P. Causative Genes in Amyotrophic Lateral Sclerosis and Protein Degradation Pathways: A Link to Neurodegeneration. Mol. Neurobiol. 2018, 55, 6480-6499. [CrossRef] [PubMed]

5. Niccoli, T.; Partridge, L.; Isaacs, A.M. Ageing as a risk factor for ALS/FTD. Hum. Mol. Genet. 2017, 26, R105-R113. [CrossRef]

6. Kuraszkiewicz, B.; Podsiadły-Marczykowska, T.; Goszczyńska, H.; Piotrkiewicz, M. Are There Modifiable Environmental Factors Related to Amyotrophic Lateral Sclerosis? Front. Neurol. 2018, 9, 220. [CrossRef]

7. Bogdanov, M.; Brown, R.H.; Matson, W.; Smart, R.; Hayden, D.; O’Donnell, H.; Flint Beal, M.; Cudkowicz, M. Increased oxidative damage to DNA in ALS patients. Free Radic. Biol. Med. 2000, 29, 652-658. [CrossRef] 
8. Cunha-Oliveira, T.; Montezinho, L.; Mendes, C.; Firuzi, O.; Saso, L.; Oliveira, P.J.; Silva, F.S.G. Oxidative Stress in Amyotrophic Lateral Sclerosis: Pathophysiology and Opportunities for Pharmacological Intervention. Oxid. Med. Cell Longev. 2020, $2020,1-29$. [CrossRef] [PubMed]

9. Ferrante, R.J.; Browne, S.E.; Shinobu, L.A.; Bowling, A.C.; Baik, M.J.; MacGarvey, U.; Kowall, N.W.; Brown, R.H., Jr.; Beal, M.F. Evidence of Increased Oxidative Damage in Both Sporadic and Familial Amyotrophic Lateral Sclerosis. J. Neurochem. 2002, 69, 2064-2074. [CrossRef]

10. Shibata, N.; Nagai, R.; Uchida, K.; Horiuchi, S.; Yamada, S.; Hirano, A.; Kawaguchi, M.; Yamamoto, T.; Sasaki, S.; Kobayashi, M. Morphological evidence for lipid peroxidation and protein glycoxidation in spinal cords from sporadic amyotrophic lateral sclerosis patients. Brain Res. 2001, 917, 97-104. [CrossRef]

11. Simpson, E.P.; Henry, Y.K.; Henkel, J.S.; Smith, R.G.; Appel, S.H. Increased lipid peroxidation in sera of ALS patients: A potential biomarker of disease burden. Neurology 2004, 62, 1758-1765. [CrossRef]

12. Rosen, D.R.; Siddique, T.; Patterson, D.; Figlewicz, D.A.; Sapp, P.C.; Hentati, A.; Donaldson, D.H.; Goto, J.; O’Regan, J.P.; Deng, H.-X.; et al. Mutations in $\mathrm{Cu} / \mathrm{Zn}$ superoxide dismutase gene are associated with familial amyotrophic lateral sclerosis. Nature 1993, 362, 59-62. [CrossRef]

13. Al-Chalabi, A.; van den Berg, L.H.; Veldink, J. Gene discovery in amyotrophic lateral sclerosis: Implications for clinical management. Nat. Rev. Neurol. 2017, 13, 96-104. [CrossRef] [PubMed]

14. Corcia, P.; Camu, W.; Brulard, C.; Marouillat, S.; Couratier, P.; Camdessanche, J.P.; Cintas, P.; Vershueren, A.; Soriani, M.H.; Desnuelle, C.; et al. Effect of Familial clustering in the genetic screening in 235 French ALS families. J. Neurol. Neurosurg. Psychiatry 2021. [CrossRef]

15. Eleutherio, E.C.A.; Silva Magalhães, R.S.; de Araújo Brasil, A.; Monteiro Neto, J.R.; de Holanda Paranhos, L. SOD1, More than just an antioxidant. Arch. Biochem. Biophys. 2020, 697, 108701. [CrossRef] [PubMed]

16. Guégan, C.; Vila, M.; Rosoklija, G.; Hays, A.P.; Przedborski, S. Recruitment of the Mitochondrial-Dependent Apoptotic Pathway in Amyotrophic Lateral Sclerosis. J. Neurosci. 2001, 21, 6569-6576. [CrossRef] [PubMed]

17. Liu, R.; Althaus, J.S.; Ellerbrock, B.R.; Becker, D.A.; Gurney, M.E. Enhanced oxygen radical production in a transgenic mouse model of familial amyotrophic lateral sclerosis. Ann. Neurol. 1998, 44, 763-770. [CrossRef]

18. Watanabe, M.; Dykes-Hoberg, M.; Culotta, V.C.; Price, D.L.; Wong, P.C.; Rothstein, J.D. Histological Evidence of Protein Aggregation in Mutant SOD1 Transgenic Mice and in Amyotrophic Lateral Sclerosis Neural Tissues. Neurobiol. Dis. 2001, 8, 933-941. [CrossRef]

19. Lee, D.-Y.; Jeon, G.S.; Sung, J. ALS-Linked Mutant SOD1 Associates with TIA-1 and Alters Stress Granule Dynamics. Neurochem. Res. 2020, 45, 2884-2893. [CrossRef]

20. Hozumi, I. Roles and therapeutic potential of metallothioneins in neurodegenerative diseases. Curr. Pharm. Biotechnol. 2013, 14, 408-413. [CrossRef]

21. Ono, S.-I. Metallothionein is a Potential Therapeutic Strategy for Amyotrophic Lateral Sclerosis. Curr. Pharm. Des. 2018, 23, 5001-5009. [CrossRef]

22. Michelle, C.; Vourc'H, P.; Mignon, L.; Andres, C.R. What Was the Set of Ubiquitin and Ubiquitin-Like Conjugating Enzymes in the Eukaryote Common Ancestor? J. Mol. Evol. 2009, 68, 616-628. [CrossRef] [PubMed]

23. Williams, K.L.; Topp, S.D.; Yang, S.; Smith, B.; Fifita, J.A.; Warraich, S.T.; Zhang, K.Y.; Farrawell, N.; Vance, C.; Hu, X.; et al. CCNF mutations in amyotrophic lateral sclerosis and frontotemporal dementia. Nat. Commun. 2016, 7, 11253. [CrossRef]

24. Perrelet, D.; Perrin, F.E.; Liston, P.; Korneluk, R.G.; MacKenzie, A.; Ferrer-Alcón, M.; Kato, A.C. Motoneuron Resistance to Apoptotic Cell Death In Vivo Correlates with the Ratio between X-Linked Inhibitor of Apoptosis Proteins (XIAPs) and Its Inhibitor, XIAP-Associated Factor 1. J. Neurosci. 2004, 24, 3777-3785. [CrossRef] [PubMed]

25. Iwata, A.; Nagashima, Y.; Matsumoto, L.; Suzuki, T.; Yamanaka, T.; Date, H.; Deoka, K.; Nukina, N.; Tsuji, S. Intranuclear Degradation of Polyglutamine Aggregates by the Ubiquitin-Proteasome System. J. Biol. Chem. 2009, 284, 9796-9803. [CrossRef]

26. Mori, T.; Ikeda, D.D.; Yamaguchi, Y.; Unoki, M. NIRF/UHRF2 occupies a central position in the cell cycle network and allows coupling with the epigenetic landscape. FEBS Lett. 2012, 586, 1570-1583. [CrossRef]

27. Reinhardt, P.; Schmid, B.; Burbulla, L.F.; Schöndorf, D.C.; Wagner, L.; Glatza, M.; Höing, S.; Hargus, G.; Heck, S.A.; Dhingra, A.; et al. Genetic Correction of a LRRK2 Mutation in Human iPSCs Links Parkinsonian Neurodegeneration to ERK-Dependent Changes in Gene Expression. Cell Stem Cell 2013, 12, 354-367. [CrossRef]

28. Lu, H.; Hallstrom, T.C. The Nuclear Protein UHRF2 Is a Direct Target of the Transcription Factor E2F1 in the Induction of Apoptosis. J. Biol. Chem. 2013, 288, 23833-23843. [CrossRef] [PubMed]

29. Cashman, N.R.; Durham, H.D.; Blusztajn, J.K.; Oda, K.; Tabira, T.; Shaw, I.T.; Dahrouge, S.; Antel, J.P. Neuroblastoma x spinal cord (NSC) hybrid cell lines resemble developing motor neurons. Dev. Dyn. 1992, 194, 209-221. [CrossRef] [PubMed]

30. Durham, H.D.; Dahrouge, S.; Cashman, N.R. Evaluation of the spinal cord neuron X neuroblastoma hybrid cell line NSC-34 as a model for neurotoxicity testing. NeuroToxicology 1993, 14, 387-395.

31. Maier, O.; Böhm, J.; Dahm, M.; Brück, S.; Beyer, C.; Johann, S. Differentiated NSC-34 motoneuron-like cells as experimental model for cholinergic neurodegeneration. Neurochem. Int. 2013, 62, 1029-1038. [CrossRef]

32. Heck, M.V.; Azizov, M.; Stehning, T.; Walter, M.; Kedersha, N.; Auburger, G. Dysregulated expression of lipid storage and membrane dynamics factors in Tia1 knockout mouse nervous tissue. Neurogenetics 2014, 15, 135-144. [CrossRef] [PubMed] 
33. Zhang, Y.; Cook, A.; Kim, J.; Baranov, S.V.; Jiang, J.; Smith, K.; Cormier, K.; Bennett, E.; Browser, R.P.; Day, A.L.; et al. Melatonin inhibits the caspase-1/cytochrome c/caspase-3 cell death pathway, inhibits MT1 receptor loss and delays disease progression in a mouse model of amyotrophic lateral sclerosis. Neurobiol. Dis. 2013, 55, 26-35. [CrossRef]

34. Tokuda, E.; Okawa, E.; Watanabe, S.; Ono, S. Overexpression of metallothionein-I, a copper-regulating protein, attenuates intracellular copper dyshomeostasis and extends lifespan in a mouse model of amyotrophic lateral sclerosis caused by mutant superoxide dismutase-1. Hum. Mol. Genet. 2014, 23, 1271-1285. [CrossRef] [PubMed]

35. Tanji, K.; Kamitani, T.; Mori, F.; Kakita, A.; Takahashi, H.; Wakabayashi, K. TRIM9, a novel brain-specific E3 ubiquitin ligase, is repressed in the brain of Parkinson's disease and dementia with Lewy bodies. Neurobiol. Dis. 2010, 38, 210-218. [CrossRef] [PubMed]

36. Zeng, J.; Wang, Y.; Luo, Z.; Chang, L.-C.; Yoo, J.S.; Yan, H.; Choi, Y.; Xie, X.; Deverman, B.E.; Gradinaru, V.; et al. TRIM9-Mediated Resolution of Neuroinflammation Confers Neuroprotection upon Ischemic Stroke in Mice. Cell Rep. 2019, 27, 549-560.e6. [CrossRef]

37. Winkle, C.C.; McClain, L.M.; Valtschanoff, J.G.; Park, C.S.; Maglione, C.; Gupton, S.L. A novel Netrin-1-sensitive mechanism promotes local SNARE-mediated exocytosis during axon branching. J. Cell Biol. 2014, 205, 217-232. [CrossRef]

38. Kawamata, H.; Ng, S.K.; Diaz, N.; Burstein, S.; Morel, L.; Osgood, A.; Sider, B.; Higashimori, H.; Haydon, P.G.; Manfredi, G.; et al. Abnormal intracellular calcium signaling and SNARE-dependent exocytosis contributes to SOD1G93A astrocyte-mediated toxicity in amyotrophic lateral sclerosis. J. Neurosci. 2014, 34, 2331-2348. [CrossRef] [PubMed]

39. Kaspar, J.W.; Niture, S.K.; Jaiswal, A.K. Nrf2:INrf2 (Keap1) signaling in oxidative stress. Free. Radic. Biol. Med. 2009, 47, 1304-1309. [CrossRef]

40. Kanno, T.; Tanaka, K.; Yanagisawa, Y.; Yasutake, K.; Hadano, S.; Yoshii, F.; Hirayama, N.; Ikeda, J.-E. A novel small molecule, N-(4-(2-pyridyl)(1,3-thiazol-2-yl))-2-(2,4,6-trimethylphenoxy) acetamide, selectively protects against oxidative stress-induced cell death by activating the Nrf2-ARE pathway: Therapeutic implications for ALS. Free. Radic. Biol. Med. 2012, 53, $2028-2042$. [CrossRef]

41. Kirby, J.; Halligan, E.; Baptista, M.J.; Allen, S.; Heath, P.R.; Holden, H.; Barber, S.C.; Loynes, C.A.; Wood-Allum, C.A.; Lunec, J.; et al. Mutant SOD1 alters the motor neuronal transcriptome: Implications for familial ALS. Brain 2005, 128, 1686-1706. [CrossRef] [PubMed]

42. Vallée, A.; LeCarpentier, Y.; Guillevin, R.; Vallée, J.-N. Aerobic glycolysis in amyotrophic lateral sclerosis and Huntington's disease. Rev. Neurosci. 2018, 29, 547-555. [CrossRef] [PubMed]

43. Pinto, C.; Cárdenas, P.; Osses, N.; Henríquez, J.P. Characterization of Wnt/ $\beta$-catenin and BMP/Smad signaling pathways in an in vitro model of amyotrophic lateral sclerosis. Front. Cell. Neurosci. 2013, 7, 239. [CrossRef]

44. Yu, Y.; Nakagawa, T.; Morohoshi, A.; Nakagawa, M.; Ishida, N.; Suzuki, N.; Aoki, M.; Nakayama, K. Pathogenic mutations in the ALS gene CCNF cause cytoplasmic mislocalization of Cyclin F and elevated VCP ATPase activity. Hum. Mol. Genet. 2019, 28, 3486-3497. [CrossRef] [PubMed]

45. Dangoumau, A.; Verschueren, A.; Hammouche, E.; Papon, M.-A.; Blasco, H.; Cherpi-Antar, C.; Pouget, J.; Corcia, P.; Andres, C.R.; Vourc'H, P. A novel SOD1 mutation p.V31A identified with a slowly progressive form of amyotrophic lateral sclerosis. Neurobiol. Aging 2014, 35, 266.e1-266.e4. [CrossRef]

46. Régal, L.; Vanopdenbosch, L.; Tilkin, P.; Van den Bosch, L.; Thijs, V.; Sciot, R.; Robberecht, W. The G93C mutation in superoxide dismutase 1: Clinicopathologic phenotype and prognosis. Arch. Neurol. 2006, 63, 262-267. [CrossRef]

47. Saeed, M.; Yang, Y.; Deng, H.-X.; Hung, W.-Y.; Siddique, T.; Dellefave, L.; Gellera, C.; Andersen, P.M. Age and founder effect of SOD1 A4V mutation causing ALS. Neurology 2009, 72, 1634-1639. [CrossRef]

48. Cookson, M.R.; Menzies, F.M.; Manning, P.; Eggett, C.J.; Figlewicz, D.A.; McNeil, C.J.; Shaw, P.J. Cu/Zn superoxide dismutase (SOD1) mutations associated with familial amyotrophic lateral sclerosis (ALS) affect cellular free radical release in the presence of oxidative stress. Amyotroph. Lateral Scler. Other Motor Neuron Disord. 2002, 3, 75-85. [CrossRef] [PubMed]

49. Martin, L.J. p53 Is Abnormally Elevated and Active in the CNS of Patients with Amyotrophic Lateral Sclerosis. Neurobiol. Dis. 2000, 7, 613-622. [CrossRef]

50. Peuget, S.; Bonacci, T.; Soubeyran, P.; Iovanna, J.L.; Dusetti, N. Oxidative stress-induced p53 activity is enhanced by a redoxsensitive TP53INP1 SUMOylation. Cell Death Differ. 2014, 21, 1107-1118. [CrossRef] [PubMed]

51. Saville, M.K.; Sparks, A.; Xirodimas, D.P.; Wardrop, J.; Stevenson, L.F.; Bourdon, J.-C.; Woods, Y.L.; Lane, D.P. Regulation of p53 by the ubiquitin-conjugating enzymes UbcH5B/C in vivo. J. Biol. Chem. 2004, 279, 42169-42181. [CrossRef]

52. Boutahar, N.; Wierinckx, A.; Camdessanche, J.P.; Antoine, J.-C.; Reynaud, E.; Lassabliere, F.; Lachuer, J.; Borg, J. Differential effect of oxidative or excitotoxic stress on the transcriptional profile of amyotrophic lateral sclerosis-linked mutant SOD1 cultured neurons. J. Neurosci. Res. 2011, 89, 1439-1450. [CrossRef] [PubMed]

53. Oliveira, G.P.; Alves, C.J.; Chadi, G. Early gene expression changes in spinal cord from SOD1G93A Amyotrophic Lateral Sclerosis animal model. Front. Cell. Neurosci. 2013, 7, 216. [CrossRef] [PubMed]

54. Das, A.; Smith, J.A.; Gibson, C.; Varma, A.K.; Ray, S.K.; Banik, N.L. Estrogen receptor agonists and estrogen attenuate TNF- $\alpha-$ induced apoptosis in VSC4.1 motoneurons. J. Endocrinol. 2010, 208, 171-182. [CrossRef]

55. Oh, Y.; Chung, K.C. UHRF2, a Ubiquitin E3 Ligase, Acts as a Small Ubiquitin-like Modifier E3 Ligase for Zinc Finger Protein $131^{*}$. J. Biol. Chem. 2013, 288, 9102-9111. [CrossRef] 
56. Trappe, R.; Buddenberg, P.; Uedelhoven, J.; Gläser, B.; Buck, A.; Engel, W.; Burfeind, P. The murine BTB/POZ zinc finger gene Znf131: Predominant expression in the developing central nervous system, in adult brain, testis, and thymus. Biochem. Biophys. Res. Commun. 2002, 296, 319-327. [CrossRef]

57. Jacobs, S.B.R.; Basak, S.; I Murray, J.; Pathak, N.; Attardi, L.D. Siva is an apoptosis-selective p53 target gene important for neuronal cell death. Cell Death Differ. 2007, 14, 1374-1385. [CrossRef] [PubMed]

58. Huang, D.W.; Sherman, B.T.; Lempicki, R.A. Systematic and integrative analysis of large gene lists using DAVID bioinformatics resources. Nat. Protoc. 2009, 4, 44-57. [CrossRef]

59. Broom, W.J.; Russ, C.; Sapp, P.C.; McKenna-Yasek, D.; Hosler, B.A.; Andersen, P.M.; Brown, R.H. Variants in candidate ALS modifier genes linked to $\mathrm{Cu} / \mathrm{Zn}$ superoxide dismutase do not explain divergent survival phenotypes. Neurosci. Lett. 2006, 392, 52-57. [CrossRef] [PubMed] 